\title{
IMPACT OF OIL PRICES ON STOCK MARKET DEVELOPMENT IN SELECTED OIL EXPORTING SUB-SAHARAN AFRICAN COUNTRIES
}

\author{
Adewale T. Muritala ${ }^{1}$, Adeniyi M. IJaiya ${ }^{2}$, Ahmed O. Adekunle ${ }^{3}$, \\ IBRAHEEM K. NAGERI ${ }^{4}$, A. BOLAJI YINUS ${ }^{5}$
}

Abstract

\begin{abstract}
This study examines the dynamic impacts of oil prices on stock market development in four oil exporting sub-Saharan African countries in the period of 1989-2015. The Arbitrage Pricing Theory (APT) is used as the theoretical framework where stock market prices are hypothesized to be fully reflective of all available information. Static panel data (Pooled OLS, panel Fixed Effect Model, panel Random Effect Model) and dynamic panel model of Generalized Method of Moments (GMM) were employed in the estimation. The estimation of the static panel model shows that oil prices, exchange rates, gross domestic product, inflation and the corruption index have a positive and significant impact on stock market development. However, there is a slight improvement from the estimation of the GMM dynamic panel model which confirmed that oil prices, exchange rates, gross domestic product, investment, inflation and the corruption index have a positive and significant impact on stock market development. The study therefore recommends that investors in selected the SubSahara Africa (SSA) stock market need to be cognizant of the varying impacts of macroeconomic indicators, particularly those that have been found to exert strong influence on stock returns like oil prices, exchange rates, inflation and the corruption index.
\end{abstract}

\footnotetext{
${ }^{1}$ Department of Accounting and Finance, Fountain University Osogbo, Nigeria, e-mail: muritaiwo237@gmail.com, ORCID: 0000-0002- 9946-0159.

2 Department of Finance, University of Ilorin, Kwara State, Nigeria, ORCID: 0000-0002-6981-0924.

${ }^{3}$ Department of Accounting \& Finance, Kwara State University, Molete, Kwara State, Nigeria.

${ }^{4}$ Department of Accounting\& Finance, Al-Hikmah University, Kwara State, Nigeria.

5 Department of Accounting, University of Ilorin, Kwara State, Nigeria, ORCID: 0000-0003-4266-4764.
} 


\section{INTRODUCTION}

The increasing awareness of investors of the relationship between oil prices and stock market development in selected oil producing Sub Sahara African (SSA) countries has received considerable attention around the globe. The stock market on the one hand serves as a barometer ofa country's economic conditions. Hence, it is widely believed that the behavior of a stock market depends on both economic performance and the political environment of the country. On the other hand, oil is an important source of energy that is important for maintaining smooth economic performance of industries that depend on oil or oil products.

Recent oil price fluctuations ( $75.4 \%$ increase between 2001 and 2008 and a 17.8\% decrease between 2008 and 2010 while there was an increase of $28.5 \%$ from 2010 to 2013 and a decrease of $41.2 \%$ from 2013 to 2019) have led this study to revisit and re-examine the impact of oil prices on stock market development in Sub-Sahara Africa (SSA). The African countries chosen for this study are the oil producing emerging economies which rely heavily on oil exports. While there is no general consensus in the empirical literature regarding the existence and nature of a relationship between oil prices and stock market development, many of these studies have indeed showed that oil price changes had significant effects on macroeconomic environments (Crunado \& Garcia, 2005; Kilian, 2008; Cologne \& Manera, 2008). However, not many studies have been done on the relationship between oil price changes and stock market development in general and especially in Sub-Saharan Africa countries. The very few studies that have examined the interaction between oil price changes and stock markets are mainly on a few industrialized net oil-importing countries such as the USA, UK and Japan (Jones \& Kaul, 1996; Sadorsky, 1999). Moreover, there is also a possibility of unobservable macroeconomic and institutional factors that determine the nature of the relationship between oil prices and stock market development.

There are many reasons for examining the impact of oil prices on stock market development in Sub-Sahara Africa (SSA). First, the literature indicates both positive and negative impacts of oil prices on stock market development and this study attempts to reveal for policy makers whether the impacts are positive or negative in the Sub-Sahara African (SSA) region. Secondly, this is to the best of the authors' knowledge the first study to investigate the impact of oil prices on stock market development in Sub-Sahara Africa (SSA) by adopting a balanced panel of generalized method of moment (GMM) systems approach for four Sub-Sahara African (SSA)stock markets (Nigeria, South Africa, Egypt and Sudan) during the period 1989 - 2015. Secondly, most studies which have been done in the past on the same have focused on specific macroeconomic factors. The present study focuses on both the macroeconomic as well as institutional factors as determinants of stock market development. Finally, this study adds valuable knowledge about emerging economies in Africa that are also oil exporters. Hence, the need to provide further evidence on the impact of oil prices on stock market development in Sub-Sahara Africa (SSA) is of paramount interest to investors, regulators, academics, and the economy in general. The rest of the paper is organized as follows. Section 2 reviews the literature. Section 3 presents the methodology used in this study. Section 4 discusses the results. Finally, Section 5 gives the conclusion and policy recommendations.

\section{LITERATURE REVIEW}

There are two main concepts underlying this study. The first is oil price fluctuation while the second is the concept of stock market development. Beginning with the latter, the stock market can be defined as the market in which shares of publicly held companies are issued and traded either through exchanges or over-the-counter markets (Yadirichukwu \& Ogochukwu, 2014). The stock market is also a market which deals in long term loans (Jhingan, 2004). It supplies firms with fixed and working capital and finances medium term and long-term borrowings of the federal, state and local governments. Underlying this definition are two hypotheses: first, that price movements are not considered shocks unless they pass a relative threshold, and second, that only positive price movements matter.

The main theory underpinning this study is the Arbitrage Pricing Theory (APT) developed by Ross (1976) which is a general theory of asset pricing that holds that the expected return of a financial asset can be modeled as a linear function of various macro-economic factors and institutional factors, where sensitivity to changes in each factor is represented by a factor-specific beta coefficient. The APT begins with an assumption on the 
return generating factors.

Previous research has worked on the relationship between oil and stock market prices for many countries around the world. This study aims to evaluate the impact of oil prices on stock market development in selected countries in Sub-Sahara Africa (SSA). The results from previous studies differ as a result of geographical factors. Some researches on one hand investigated the effects of oil prices on stock markets in developed countries [Jones \& Kaul, (1996); Sadorsky, (1999); Papapetrou, (2001); Anoru \& Mustafa, (2007), Miller \& Ratti, (2009); Taheri, (2014)] while others explored the relationship between oil prices and stock prices in emerging and developing countries [Brasher, (2004); Maghyereh, (2004); Narayan \& Narayan, (2010); Ramos \& Veiga, (2010); Imarhiagbe, (2010); Muritala, Taiwo \& Olowookere, (2012); Anthony, (2012); Aderamola, (2012); Asaolu \& Ilo, (2012); Ogiri, Amadi, Uddin \& Dubon, (2013); Itotenaan, Amadi, Moshfique \& Dubon, (2013), Akinlo, (2014)].

Jones and Kaul (1996) studied the response of international stock markets to changes in the oil prices using quarterly data. The study focused on stock returns from the USA, Canada, the UK, and Japan, utilized simple regression models, and reported that the stock returns for all countries (except the UK) were negatively impacted by oil prices. Sadorsky (1999) used monthly data to probe the relationship between oil prices and stock returns for the USA from January 1947 to April 1996. The author applied variance decomposition. The findings suggested that oil prices and stock returns have a negative relationship in the short term, meaning higher oil prices lead to lower stock returns. Papapetrou (2001) applied vector error correction modeling to study the effect of oil prices on stock returns for Greece using daily data and the variance decomposition. The study suggested a negative oil price effect on stock returns that extended over four months.

Anoruo and Mustafa (2007) examined the relationship between oil and stock returns for the USA using daily data, Johansen Bivariate Cointegration, and error-correction approach. They found long-run relationship between oil and stock returns in the USA. The estimated Vector-ErrorCorrection Model (VECM) provided evidence of causality from stock market returns to oil market and not vice versa. Although the Johansen and Juselius estimation technique did not yield evidence of cointegration, the GregoryHansen cointegration tests provided evidence of both oil and stock markets being cointegrated. The authors stated that this result implied that both markets are integrated and not segmented. Consequently, the authors believed that diversifying in both markets will not create benefits for the investors holding the portfolio because of the integration of the markets, and that risk minimization through portfolio diversification are unattainable by holding assets in oil and stock markets.

The study by Miller and Ratti (2009) looked at the relationship between world prices of oil and international stock markets. The results of the analysis showed that stock market indices responded negatively to increases in oil prices in the long run. However, according to them, this pattern appeared to disintegrate from the beginning of 2000. Taheri (2014) investigated the impact of oil prices on the stock market of the UK, Canada, USA and France in the terms of real stock returns; the data used in this study was monthly data from 1990 to 2012 using ECM. Their result showed that the response of Canada as an oil producer to the increase of oil was positive and the impact was shown in the first month, the remaining countries which were oil consumers responded to this change negatively.

Brasher (2004) in his analysis on the effect of oil prices on stock market documents, found that all sectors are not affected equally, or at the same time. He found that when oil prices rise, cyclical stocks are the most negatively influenced, cyclical consumer goods are the next most negatively influenced, and lastly financials are the next most negatively influenced. According to the documentation cyclical stocks include general retailers, support services, leisure industries and hotels, entertainment and media. Cyclical consumer goods comprise household goods and textiles, automobiles and parts, while the financials are the investment companies, banks, especially, and other finance industries such as life assurance and insurance and real estate. Beyond this analysis, it is also obvious that stock prices are inversely related in the USA.

Maghyereh (2004) studied the dynamic linkage between oil prices and stock returns in 22 emerging economies using the unrestricted Vector Autoregressive (VAR) approach. The research investigated the effectiveness of innovations in the transmission from oil market to emerging equity markets, utilizing forecast error variance decomposition and impulse response analysis. According to the author, a plot of each emerging equity market response to a shock in the oil price suggested a gradual transmission with the equity market reacting to the shock two days afterwards. While the speed of adjustment slowly declined to zero on the fourth day in 16 countries, 
the response continued to the seventh day in Argentina, Brazil, China, Czech Republic, Egypt, and Greece. The impulse response demonstrated gradual diffusion of innovations from the oil market into the emerging equity markets. Furthermore, the author postulated the slow adjustment to imply the presence of inefficiency in the emerging equity market transmission of innovations from the oil market. The variance decomposition revealed very weak evidence of cointegration between oil price shocks and stock market returns. In addition, the author stated that the oil market is an ineffective influence on the equity market because the sizes of responses are very small.

Narayan and Narayan (2010) assessed the relationship between oil prices and Vietnam's stock prices with a daily series from 2000 to 2008. Using the Johansen test, the findings provided evidence of oil prices, stock prices, and exchange rates for Vietnam sharing a long-run relationship. In addition, the study found both oil prices and exchange rates have a positive and statistically significant effect on Vietnam's stock prices in the long-run and not in the short-run. According to Ramos and Veiga (2010), there is no consistent evidence that can serve as a basis to assert a decisive influence on oil prices in world stock markets. They analyzed the exposure of a large sample of stock markets to oil price fluctuations. According to these authors, the strong fluctuations of these oil prices lead to a rising stock market. However, the drop in this price does not necessarily increase the performance of the stock market. The negative impact caused by oil prices in the stock market only applies to the developed nations but on the contrary, the stock markets of developing nations are not sensitive to the price changes.

Imarhiagbe (2010), analyzed the impact of oil prices on stock prices of selected major oil producing and consuming countries with nominal exchange rate as an additional determinant. Daily stock prices, oil prices, and exchange rates for six countries (Mexico, Russia, Saudi Arabia, India, China, and the USA) from January 26, 2000 to January 22, 2010, are modeled as a co-integrated system in Vector Autoregressive analysis. Variance decompositions and impulse responses are also estimated. Their results support unit root in all variables (except Saudi Arabia and the USA exchange rates that are stationary in levels and first difference). Evidence of one long-run relationship (Mexico inconclusive) in Saudi Arabia, India, China and the USA is supported, while Russia exhibits two long-run relationships. The results from the long-run exclusion test suggest all three variables cannot be eliminated from co- integrating space in all countries (except Mexico), while the weak exogeneity test reveals all variables to be responsive to deviation from long-run relationships (except China).

Muritala, Taiwo and Olowookere (2012) investigated the impact of crude oil price and stock price on some selected macroeconomic indicators in Nigeria using cointegration and error correction on time series data from 1980 to 2010 . The findings reveal that crude oil price, stock price and exchange rate are significant in determining the growth of the Nigerian economy. Anthony (2012) examined the long-run and short-run dynamic effects of oil price on stock returns in Nigeria over 1985-2009 by using the Johansen co-integration tests. A bivariate model was specified and empirical results show a significant positive stock return to oil price shock in the short-run and a significant negative stock return to oil price shock in the long-run.

Aderamola (2012) examined the long-run and shortrun dynamic effects of oil price on stock returns in Nigeria using the Johansen co-integration and granger causality tests on time series data from 1985 to 2009. The empirical results showed a significant positive stock return to oil price shock in the short-run and a significant negative stock return to oil price shock in the long-run while the granger causality test showed strong evidence that the causation runs from oil price shock to stock returns. Asaolu and Ilo (2012) investigated the relationship between the Nigerian stock market return and the world crude oil price which was analysed under the co-integration and vector error correction (VECM) framework from 1984 to 2007. They found that the Nigerian stock market return and oil price are co-integrated in the long run due to the dominance of the oil sector on the Nigerian economy.

Ogiri et al. (2013) examined the impact of oil price on stock market performance in Nigeria using (VECM), the result showed that oil price changes are an important factor in explaining the stock price movement. Itotenaan et al. (2013) investigated the relationship between oil prices and stock market performance in Nigeria using different empirical methods which include the Vector error correction model (VECM) and the Vector auto regression (VAR) model. Akinlo (2014) examined the relationship between changes in oil prices and stock market growth over the period 1981-2011 using the vector error correction modeling approach which suggested a long run relationship between oil price, exchange rate and stock market growth. 


\section{METHODOLOGY}

The study used quantitative research design with a set of regression estimates in testing the impact of oil price on stock market development in Sub-Sahara Africa (SSA). Stock market development was proxied by market capitalization as a ratio of GDP (MKCAP). It serves as the dependent variable. The independent variables involve oil price (OILPR), exchange rate (EXCRT). Gross domestic product (GDP), investment (INVTM) inflation (INF), corruption index (COINDEX) and political instability (POSINDEX).The data were obtained from the World Development Indicator (WDI),National Bureau of Statistics (NBS) and International Financial Statistics (IFS) and Transparency International.

The study seeks to examine the impact of oil prices on stock market development in selected Sub-Sahara African (SSA) oil producing countries from 1989 to 2015. The choice of 1989 is informed by the choice of uniform years through which the selected Sub-Sahara African (SSA) countries under study had their stock markets expanded considerably after 1989 (Sebnet \& Ochere, 2008). Hence, Nigeria, South Africa, Egypt and Sudanwere the countries who apart from having a well-developed stock market, were also oil producing and exporting countries and each of these countries represent different regions in Africa West Africa, South Africa, North Africa and East Africa, respectively.

The methodology adopted in deriving the index for institutional quality for this study follows the line of thought in Akanbi (2012) when measuring governance. Given this, the worldwide governance indicators developed by Kaufmann et al (1999a) were utilised as a measure of institutional quality (Kraay \& Nehru, 2006). Since the governance indicators series are only available from 1996 onwards and in order to capture policy and institutions for the missing values for 1995 backward, the Freedom House Index (FHI) is used to augment all unavailable values on the corruption perception index and political instability.

\section{Model SPecification}

This study relies on the Arbitrage Pricing Theory (APT) which uses multiple risk factors to explain security returns of an asset as the theoretical framework. This theory predicts that any anticipated or unanticipated arrival of new information about oil prices, exchange rate, gross domestic product, inflation, investment, corruption index and political instability will alter stock prices/returns (Chinzara, 2011).

The APT formula is:

$$
\begin{aligned}
& E\left(r_{j}\right)=r_{f}+b_{j 1} R P_{1}+b_{j 2} R P_{2}+b_{j 3} R P_{3}+b_{j 4} R P_{4}+ \\
& +\ldots+b_{j n} R P_{n}
\end{aligned}
$$

where:

$E\left(r_{j}\right)=$ the asset's expected rate of return,

$r_{f}=$ the risk-free rate,

$b_{j}=$ the sensitivity of the asset's return to the particular factor,

$R P=$ the risk premium associated with the particular factor.

The general idea behind APT is that two things can explain the expected return on a financial asset: 1 ) macroeconomic/security-specific influences and 2) the asset's sensitivity to those influences. This relationship takes the form of the linear regression formula above. There are an infinite number of security-specific influences for any given security including oil price, exchange rate, gross domestic product, inflation, investment, corruption index and political instability.

This study modifies the model as:

$$
\begin{aligned}
& \text { MKCAP }_{i t}=\alpha+b_{1} \text { OILPR }_{i t}+b_{2} \text { EXCRT }_{i t}+ \\
& +b_{3} \text { GDP }_{i t}+b_{4} I N V T M_{i t}+b_{5} I N F_{i t}+ \\
& +b_{6} \text { COINDEX }_{i t}+b_{7} \text { POSINDEX }_{i t}+\varepsilon_{t}
\end{aligned}
$$

\section{Static And Dynamic Modeling}

Estimations for the impact of oil price on stock market development were done using the following variables: MKCAP - stock market capitalization as ratio of GDP is taken to be the dependent variable, OILPR - oil price, EXCRT exchange rate, GDP - gross domestic product, INVTM investment, INF - inflation, COINDEX - Corruption index, POSINDEX - Political instability index. The study used a static model given as follows:

$$
\begin{aligned}
& \text { MKCAP }_{i t-1}=\alpha+b_{1} \text { OILPR }_{i t-1}+b_{2} E X C R T_{i t-1}+b_{3} G D P_{i t-1}+ \\
& +b_{4} I_{i N T M}+b_{5} I N F_{i t-1}+b_{6} \text { COINDEX }_{i t-1}+ \\
& +b_{7} \text { POSINDEX }_{i t-1}+\varepsilon_{t}
\end{aligned}
$$

The study used also the dynamic model for comparison purposes with static model as follows:

$$
\begin{aligned}
& \text { MKCAP }_{i t-1}=\alpha+b_{1} \text { OILPR }_{i t-1}+b_{2} \text { EXCRT }_{i t-1}+b_{3} G D P_{i t-1}+ \\
& +b_{4} \text { INVTM }_{i t-1}+b_{5} I N F_{i t-1}+b_{6} \text { COINDEX }_{i t-1}+ \\
& +b_{7} \text { POSINDEX }_{i t-1}+\varepsilon_{t}
\end{aligned}
$$


In models (3) and (4) the coefficients are represented by $\beta 1 \ldots \ldots \ldots \ldots \ldots \ldots \ldots . . . . . . . . . . . . .38$ and the value of one less the coefficients of the lagged dependent variables measures the speed of adjustment towards the desired level of oil price and stock market development. If the value is greater than zero then there will be transaction costs as countries adjust to the desired level.

\section{FINDINGS AND DISCUSSION}

\section{Unit Root Test}

The unit root tests for non-stationarity (that is, Levin, Lin \& Chut; Im, Pesaran \& Shin W-stat tests) as shown in Table 1 fail to reject the null hypothesis of stationarity at $5 \%$ level for all the variables in level terms. The unit root tests therefore show strong evidence that market capitalization, oil price, exchange rate, gross domestic product, investment, inflation rate, corruption index and political instability are stationary and are integrated of order one that is, I(1) for all periods at 5 percent level of significance.

\section{Descriptive Statistics Results}

As observed in Table 1, LOG (GDP) has the lowest mean value of 6.516483 and OILPR has the highest mean value of 47.99473 whereas the mean value of MKCAP, COINDEX, EXCRT, INF, INVTM and POSINDEX are 46.31525, 15.02926, 29.14658, 16.54894, 18.60061 and 10.63526 respectively. The standard deviation measures how concentrated the data are around the mean, hence it can be observed from the study that market capitalization is the largest while the gross domestic product is the lowest giving the implication that the values for the operational data values are further from the mean on averages. The measure of how asymmetric a distribution can be is called skewness. All the variables were positively skewed except gross domestic product and investment, meaning that the

Table 1: Unit Root Test

\begin{tabular}{|c|c|c|c|c|c|}
\hline \multirow[b]{2}{*}{ Variables } & \multicolumn{2}{|c|}{ Level } & \multicolumn{2}{|c|}{ Difference } & \multirow{2}{*}{$\begin{array}{c}\text { Order in } \\
\text { Integration }\end{array}$} \\
\hline & Levin, Lin \& Chu t* & $\begin{array}{l}\text { Im, Pesaran and } \\
\text { Shin W-stat }\end{array}$ & Levin, Lin $\&$ Chu $\mathrm{t} *$ & $\begin{array}{l}\text { Im, Pesaran and } \\
\text { Shin W-stat }\end{array}$ & \\
\hline MKCAP & -0.90506 & -0.30992 & $-3.68579 * *$ & $-5.30224 * *$ & $1(1)$ \\
\hline OILPR & -0.20024 & 0.47531 & $-3.32908 * *$ & $-1.79233^{* *}$ & $1(1)$ \\
\hline EXCRT & -0.11496 & -0.16082 & $-4.48394 * *$ & $-4.26710 * *$ & $1(1)$ \\
\hline GDP & -0.36516 & -0.68941 & $-1.24491^{* *}$ & $-1.88584^{* *}$ & $1(1)$ \\
\hline INVTM & -1.79459 & -2.65561 & $-5.48327^{* *}$ & $-5.68072 * *$ & $1(1)$ \\
\hline INF & -1.09630 & -0.97254 & $-6.09953^{* *}$ & $-6.07030 * *$ & $1(1)$ \\
\hline COINDEX & -0.03578 & -0.37069 & $-0.90020 * *$ & $-6.03080 * *$ & $1(1)$ \\
\hline POSINDEX & -0.56592 & -0.97633 & $-2.52357^{* *}$ & $-5.15637^{* *}$ & $1(1)$ \\
\hline
\end{tabular}

Source: Own calculations

Table 2: Descriptive Statistics Results Test

\begin{tabular}{|c|c|c|c|c|c|c|c|c|}
\hline & MKCAP & COINDEX & EXCRT & LOG(GDP) & INF & INVTM & OILPR & POSINDEX \\
\hline Mean & 46.31525 & 15.02926 & 29.14658 & 6.516483 & 16.54894 & 18.60061 & 47.99473 & 10.63526 \\
\hline Median & 12.21662 & 0.000000 & 6.992597 & 6.345712 & 11.35000 & 18.93500 & 47.75082 & 0.000000 \\
\hline Maximum & 276.6008 & 78.53658 & 192.4400 & 10.55557 & 158.9435 & 34.92000 & 104.0621 & 56.00000 \\
\hline Minimum & 0.000000 & 0.000000 & 0.391304 & 0.506818 & 1.400000 & 0.000000 & 15.47572 & 0.000000 \\
\hline Std. Dev. & 71.22131 & 21.86087 & 44.43748 & 1.720767 & 22.51067 & 7.186938 & 25.83019 & 15.89742 \\
\hline Skewness & 1.708703 & 1.384102 & 1.721092 & -0.903014 & 4.499751 & -0.32774 & 0.707417 & 1.399253 \\
\hline Kurtosis & 4.913084 & 3.697246 & 4.909508 & 6.561399 & 25.07393 & 3.440979 & 2.546040 & 3.612921 \\
\hline Jarque-Bera & 104.8134 & 55.68557 & 105.8815 & 108.9596 & 3883.038 & 4.264959 & 15.08687 & 56.08327 \\
\hline Probability & 0.000000 & 0.000000 & 0.000000 & 0.000000 & 0.000000 & 0.000143 & 0.000530 & 0.000000 \\
\hline Observations & 164 & 164 & 164 & 164 & 164 & 164 & 164 & 164 \\
\hline
\end{tabular}

Source: Own calculations 
mass of the distribution is concentrated on the right (that is, it is said to be left-skewed. The implication of this is that the skewness tends to say more on the mean value of the distribution being higher or lower than the median. Hence, a positively skewed value indicates a higher mean value over the median value. On the part of Kurtosis, all the variables used including the oil price present positive values which means that the distribution is leptokurtic (too tall).

\section{Trend Analysis of OIL Trend Volatility in Nigeria, South Africa, Egypt and Sudan}

Between 1989 and 1992, there was a recorded 26\% hike in oil prices from \$22.88-\$23.14 per barrel but thereafter, it fell sharply to $\$ 15.48$ in 1999 due to the recovery of oil exporting and the gradual production increasing in Iraq, especially the strong impact of the Asian financial crisis on the world economy and oil demand in 1997. However, it recovered steadily and increased rapidly up to 2009 when it reached \$94.95. This increment was due to the economic resurgence brought about by increasing of crude oil demand, which caused the international oil price to rise unceasingly and up to a record high price before dropping to $\$ 79.64$ in 2010. The drop in oil price has contributed to an abrupt depreciation of currencies which makes the US dollar denominated debt more expensive and thereby leading to lower oil revenues (GDP). This may induce companies to reduce their investments and limit job creation thereby consequently harming economic growth. This tremendous event will lead to higher inflation and lower expenditure which could be a catalyst for social/political instability such as youth unemployment, with a high cost of living as considered as one of the issues that fuelled the uprising in Africa (Egypt and Nigeria - Boko Haram development). The volatility in oil prices during 2010 and 2013 mainly was due to the Arab Spring and events in Libya and conflict between Sudan and South Sudan. African economic growth rates were driven mainly by high oil prices. Thus, impact of increase in oil prices in Nigeria, South Africa, Egypt and Sudanhas led to higher budget revenues which have created room for lower tax receipts which in turn have boosted investment spending in other sectors and improvement of their balance of payments. Moreover, this increment did not last long before the price plunged back to \$49.57 per barrel in 2015 .

Figure 1: Trend Analysis of Oil Price Volatility in Nigeria, South Africa, Egypt and Sudan

Trend Analysis of Oil Price Volatility

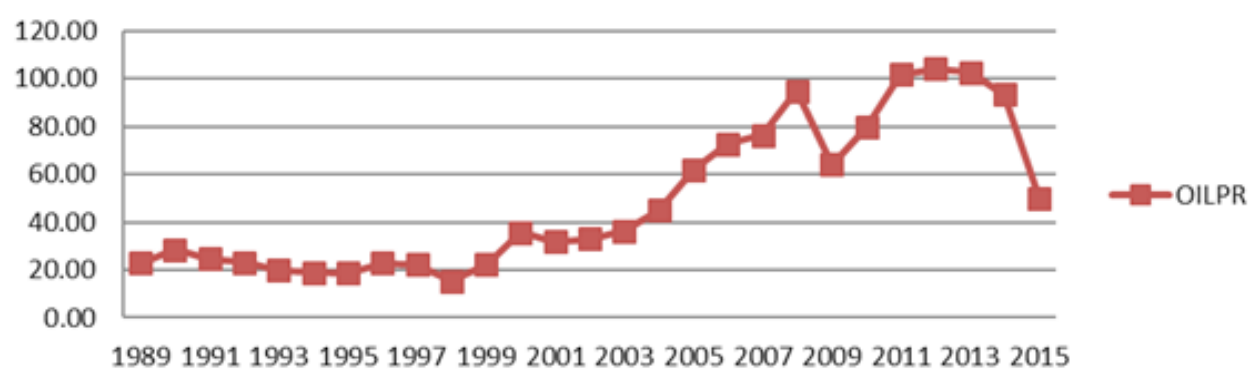

Source: Own work

Figure 2: Trend Analysis of Nigeria Market Capitalization (1989 -2015)

MKCAP - NIG

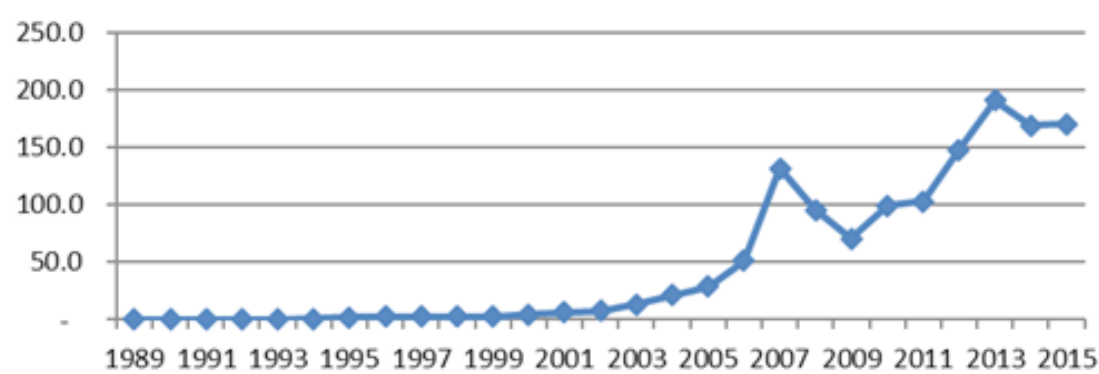

Source: Own work 


\section{Trend Analysis of Nigeria Market Capitalization}

The graph below shows a steady creeping growth between 1989 and 2002 before a recorded 124\% hiked in market capitalization from 7.6 (2002) to 131.8 (2007), but thereafter, it had a sharp fall of $62 \%$ in 2009 due to the recovery of oil exporting and the gradual production increase in Iraq. However, it recovered steadily and increased rapidly up to 2013 when it reached 190.8. This increment was due to the economic resurgence brought about by increasing of crude oil demand, which caused the international oil prices to rise unceasingly before falling to 168.8 in 2015 . The drop in the market capitalization was due to an abrupt depreciation of currencies which makes the US dollar denominated debt more expensive and thereby leading to lower oil revenues in Nigeria.

\section{Trend Analysis of South Africa Market Capitalization}

The stock market development in South Africa has shown a more or less upward trend from 1989. For example, throughout the period from 1989 to 2005, the annual stock market capitalization ratio recorded was over and above that of the 1980s. The stock market capitalization ratio increased from 116 in 1989 to 185 in 1994 and to 189 in 1995. The highest ratio was 199, which was recorded in 1999. Although the ratio subsided somewhat in 2002 to 121 . It recorded a hike of $219 \%$ from 2003 to 2007, but thereafter, it had a sharp fall of $116 \%$ in 2008 due to the recovery of oil exporting and the gradual production increase in Iraq. However, it recovered steadily and increased rapidly from 2011 up to 2014 when it reached 266.93. This increment was due to the economic resurgence brought about by increasing of crude oil demand, which caused the international oil price to rise unceasingly and up to a record high price before falling to 235.28 in 2015 .

Figure 3: Trend Analysis of South Africa Market Capitalization (1989 -2015)

MKCAP-SA

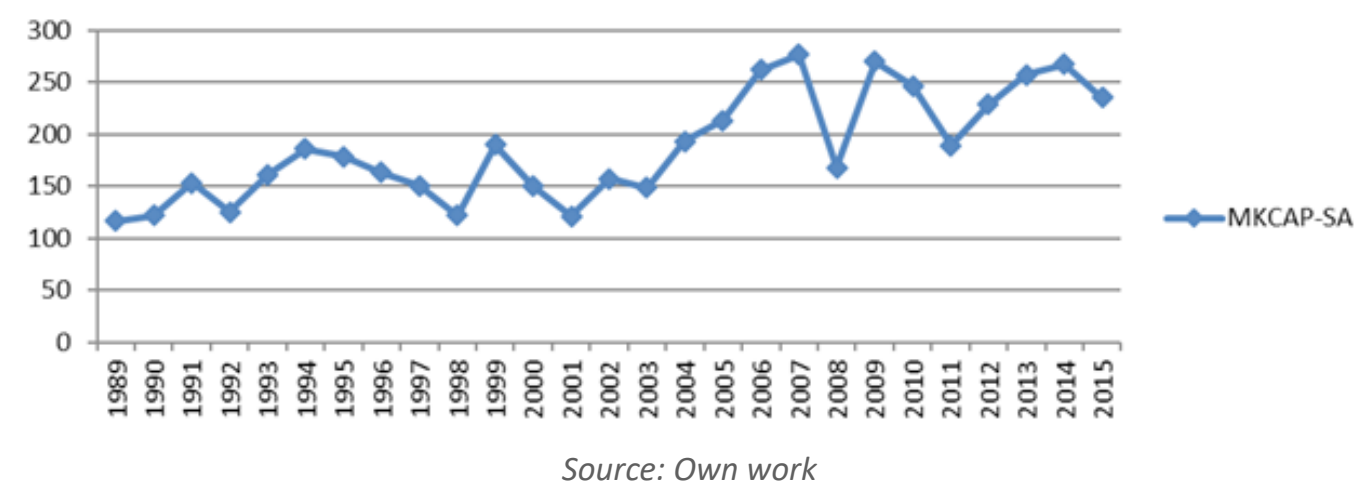

Figure 4: Trend Analysis of Egyptian Market Capitalization (1989 -2015)

MKCAP - EGY

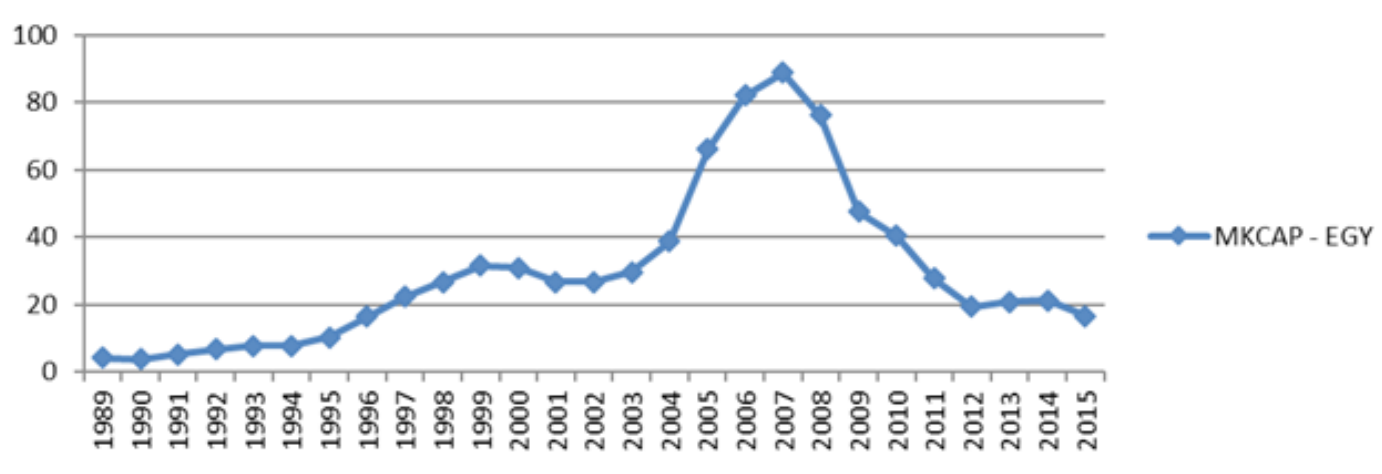

Source: Own work 


\section{Trend Analysis of the Egyptian Market Capitalization}

Between 1989 and 1994, the exchange rate was pegged to the U.S. dollar due to the rapid accumulation of foreign reserves and thereby leading to a steady creeping growth before a recorded $6 \%$ hike in market capitalization from 7.68 to 31.53 . This hike can be attributed to the introduction of economic policy reforms, the responsiveness of the market to the accelerated privatization programme of the government, increasing interest of foreign financial institutions in the Egyptian market and the enhanced performance of the Egyptian companies, which was reflected in increased profit. But thereafter, it had a sudden fall of $2 \%$ in 2002 . However, it recovered steadily and increased rapidly up to 2007 when it reached 88.73. This increment was due to the economic resurgence brought about by increasing of crude oil demand, which caused the international oil price to rise unceasingly and up to a record high price before falling to 16.8 in 2015 . The drop in the market capitalization was due tothe post-global financial crisis between 2008 and 2015 made Egypt face the long term supply- and demandside repercussions on the national economy. This even lead to socioeconomic political instability and popular revolution.

\section{Trend Analysis of Sudanese Market Capitalization}

Between 1989 and 1994, there was a steady creeping growth characterized by relatively high political instability and we witnessed two regime changes from military to democratic to military. As a result of this political instability, perceived risks of the economic environment increased especially during the early years of the 1989 military regime, which used extreme political repression, unheard of in the modern history of Sudan, as well as extreme predatory economic measuresafter which a recorded $75 \%$ hike in market capitalization from 2.4 to 9.49. This hike can be attributed to a positive growth spell in TFP due to the earlier phase of the inflow of foreign direct investment into the oil sector and the introduction of IMF/World Bank macroeconomic policy stabilization and structural adjustment reforms. But thereafter, it had a sudden fall of $35 \%$ in 2003 . However, it recovered steadily and increased rapidly up to 2006 when it reached 9.4. This increment was due to the second military regime that decided to formulate and implement structural adjustment programmes with support from the International Monetary Fund (IMF) and the World Bank before falling to 2.2 in 2015 .

Figure 5: Trend Analysis of Sudanese Market Capitalization

MKCAP - SUD

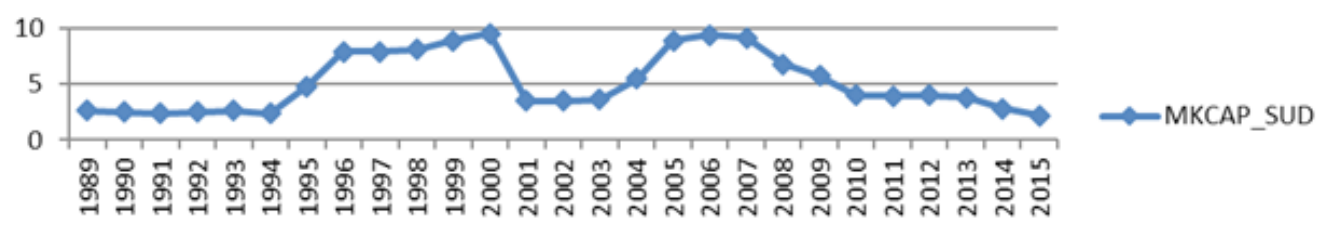

Source: Own work

Table 3: Results of Static Panel Data Analysis

\begin{tabular}{|c|c|c|c|c|c|c|c|c|c|}
\hline \multicolumn{10}{|c|}{ Static Panel Estimates } \\
\hline \multirow{2}{*}{ Variable } & \multicolumn{3}{|c|}{ Pooled OLS } & \multicolumn{3}{|c|}{ Fixed-Effects } & \multicolumn{3}{|c|}{ Random-Effects } \\
\hline & Coef. & Std. Error & P-Value & Coef. & Std. Error & P-Value & Coef. & Std. Error & P-Value \\
\hline$-C$ & -2534.6 & 1144.2 & 0.029 & -6593.8 & 1314.5 & 0.000 & -2534.6 & 1144.2 & 0.027 \\
\hline OILPR & 13.809 & 7.933 & 0.085 & 16.27 & 7.848 & 0.041 & 13.809 & 7.93 & 0.082 \\
\hline EXCRT & 40.539 & 6.312 & 0.000 & 41.21 & 6.929 & 0.000 & 40.539 & 6.31 & 0.000 \\
\hline GDP & 0.912 & 0.058 & 0.119 & 0.147 & 0.0549 & 0.009 & 0.912 & 0.058 & 0.116 \\
\hline INVTM & -34.44 & 45.12 & 0.447 & 73.59 & 56.946 & 0.199 & -34.44 & 45.12 & 0.445 \\
\hline INF & 57.098 & 12.039 & 0.000 & 36.25 & 11.124 & 0.002 & 57.098 & 12.04 & 0.000 \\
\hline COINDEX & 48.974 & 11.577 & 0.000 & 99.91 & 27.839 & 0.001 & 48.97 & 11.58 & 0.000 \\
\hline POSINDEX & -45.44 & 33.947 & 0.184 & -22.22 & 1314.5 & 0.460 & -45.44 & 33.94 & 0.181 \\
\hline
\end{tabular}




\begin{tabular}{|c|c|c|c|}
\hline R-Square & 0.7895 & 0.7865 & 0.7509 \\
\hline $\begin{array}{c}\text { Adj R- } \\
\text { Square }\end{array}$ & 0.7747 & 0.7737 & 0.7412 \\
\hline F-Stat & 0.000 & 0.000 & 0.000 \\
\hline
\end{tabular}

Source: Computed by the Researcher (2020)

Tabe 4: Tests on Panel Models

\begin{tabular}{|c|c|c|c|}
\hline Test Statistics/P-values & Poolability Test & Test Statistics/P-values & Hausman Test \\
\hline F-statistics & $53.57(0.000)$ & Chi-Square & $374.99(0.000)$ \\
\hline
\end{tabular}

Source: STATA Output

The pooled regressions results show that oil price, exchange rate, gross domestic product, inflation and corruption index are correctly signed based on theory and are in line with a-priori expectation while gross domestic product, investment and political instability are not in conformity with a-priori expectation. These varying impacts are in conformity with the earlier finding of Akinlo, (2014); Narayan and Narayan (2010); Muritala et al. (2012); Adaramola (2012). This justifies the fall in the value of the naira with respect to major international currencies in the world during the sampled period. The t-statistics show that crude oil price is significant at 10 percent, exchange rate at 1 percent inflation at 1 percent and corruption index at 1 percent while gross domestic product, investment and political instability are found to be insignificant. The $R^{2}$ and adjusted $R^{2}$ stand at 0.7895 and 0.7747 respectively and this indicates that approximately 77 percent variation in market capitalization is being jointly explained by the explanatory variables. The F-statistics of 0.000 also confirms the significance of the parameter estimates in the regression at 1 percent. The fixed effect results from table above show a similarity with the pooled data results, but with a moderate difference. Inflation rate, interest rate and exchange rate maintain their signs in line with theoretical expectation.

The explanatory variables including exchange rate, gross domestic product, inflation and corruption index are significant at 1 percent with the exception of oil price which is significant at 5 percent while investment and political instability are found to be insignificant. The $R^{2}$ within and between still confirms that 77 percent of variation in market capitalization is explained by the joint factors and F-value of 0.000 is found to be significant at 1 percent confirming the robustness of the overall regression parameters in the model. Therefore, based on the poolability test, it indicates that the fixed effect panel model is preferred to the pooled OLS model. The calculated F-statistics of 53.57 with a probability value of 0.000 is too large so that the null hypothesis is rejected at a high significant value of 1 percent.

However, the random effect outcomes by observation show no significant difference with the fixed effect results. All the variables almost maintain their outcomes. Oil price, exchange rate, gross domestic product, inflation and corruption index are correctly signed in line with theory and significant at the one percent level. This outcome is in agreement with Muritala et al. (2012); Adaramola (2012). Investment and political instability are not correctly signed but crude oil price, exchange rate, inflation and corruption index are significant at 10 percent, 1 percent, 1 percent and 1 percent while gross domestic product, investment and political instability remain insignificant at permissible levels. The $\mathrm{R}^{2}$ still confirms that 75 percent of variation in the dependent variable is explained by the explanatory variables.

The Hausman test as propounded by Hausman (1978) is formulated to assist in making a choice between fixed and random effect approaches. The test compares the estimated $(\beta)$ and variance $(\beta)$ of fixed with random effects i.e. it compares the constant estimates and the standard errors of regression of both fixed and random effects to determine whether the difference is large. Hence, the test comparing the fixed-effect and random-effect model (the Hausman test) indicates that we cannot reject the null hypothesis that the preferred model is a random effect at the 1 percent level. The Hausman test, with a Chisquare distribution has a computed value of 374.99 with probability value of 0.000 . Therefore, the random effect is more appropriate out of the three models. 
Table 5: Results of Dynamic Panel GMM

\begin{tabular}{|c|c|c|c|c|c|c|c|c|c|}
\hline \multicolumn{10}{|c|}{ Dynamic Panel Estimates } \\
\hline \multirow{2}{*}{ Variable } & \multicolumn{3}{|c|}{ Differenced Dynamic } & \multicolumn{3}{|c|}{ Systemic Dynamic } & \multicolumn{3}{|c|}{ Linear Dynamic } \\
\hline & Coef. & Std. Error & P-Value & Coef. & Std. Error & P-Value & Coef. & Std. Error & P-Value \\
\hline$-\mathrm{C}$ & -27760.2 & 1056.92 & 0.009 & -1717.8 & 705.04 & 0.015 & -7782.4 & 933.27 & 0.000 \\
\hline OILPR & 5.1033 & 5.506 & 0.354 & 5.288 & 4.702 & 0.252 & 15.78 & 5.319 & 0.000 \\
\hline EXCRT & 16.63 & 5.414 & 0.002 & 21.57 & 4.326 & 0.000 & 44.181 & 5.048 & 0.000 \\
\hline GDP & 0.480 & 0.389 & 0.217 & 0.0141 & 0.322 & 0.661 & 0.138 & 0.0272 & 0.000 \\
\hline INVTM & 62.586 & 44.71 & 0.155 & 45.99 & 22.48 & 0.661 & 115.71 & 48.59 & 0.017 \\
\hline INF & 11.044 & 7.994 & 0.167 & 17.87 & 7.011 & 0.011 & 36.76 & 7.56 & 0.000 \\
\hline COINDEX & 36.52 & 20.688 & 0.077 & 15.08 & 9.120 & 0.098 & 113.87 & 18.57 & 0.000 \\
\hline POSINDEX & -17.113 & 20.49 & 0.404 & -29.08 & 18.65 & 0.152 & -26.005 & 20.32 & 0.201 \\
\hline $\begin{array}{l}\text { Wald Chi } \\
\text { Square }\end{array}$ & \multicolumn{3}{|c|}{881.07} & \multicolumn{3}{|c|}{2204.98} & \multicolumn{3}{|c|}{2829.11} \\
\hline F-Stat & \multicolumn{3}{|c|}{0.000} & \multicolumn{3}{|c|}{0.000} & \multicolumn{3}{|c|}{0.000} \\
\hline
\end{tabular}

Source: Computed by the Researcher, (2020)

\section{Dynamic Panel Model Results}

The GMM estimation results in Table 5 present the GMM first difference estimator of Arellano and Bond (1991), as well as the GMM system estimator as developed by Arellano and Bover (1995) and Blundell and Bond (2000). The results are quite similar to the previous regressions of Pooled OLS, fixed and random effect. From the differenced dynamic panel test and the systemic dynamic panel test, it indicates that the systemic dynamic panel model is preferred to the differenced dynamic panel model. This is evident from the Wald Chi Square test value of 881.07 to 2204.98 with a probability value of 0.000.Therefore, from the systemic panel model result, onlyexchange rate and inflation are significant at 1 percent while oil price, gross domestic product, investment, corruption index and political instability remain insignificant at permissible levels.

Hence, the test comparing the systemic dynamic panel test and the linear dynamic panel test model (the Wald Chi Square test) indicates that we cannot reject the null hypothesis that the preferred model is linear dynamic panel test model at the 1 percent level. The Wald Chi Square test has a computed value of 2829.11 with probability value of 0.000 . Therefore, the linear dynamic panel model is more appropriate out of the three GMM system estimators.

Interestingly, there are three important changes that emerge from the GMM results as shown in Table 6. Firstly, all the variables (oil price, exchange rate, gross domestic product, investment, inflation and corruption index) are now significant at 1 percent in the GMM estimator. Secondly, the political instability effect in the GMM differenced, dynamic model and system estimators is negatively insignificant respectively.

\section{CONCLUSIONS \\ AND \\ POLICY RECOMMENDATIONS}

The study concludes through the static panel model estimation that oil price, exchange rate, gross domestic product, inflation and corruption index are all positively and significantly related to stock market development while investment and political instability are not. However, there is a slight improvement from the estimation of the GMM dynamic panel model which confirmed that all the variables under consideration are positively and significantly related to stock market development except political instability.

Hence, to improve portfolio performance, investors inthe Sub-Sahara African (SSA) stock market need to be cognizant of the varying impacts of macroeconomic indicators particularly those that have been found to exert strong influence on stock returns like oil price, exchange rate, inflation and corruption index. The varying impacts of macroeconomic indicators on stock returns also signal that investors can diversify and shuffle their portfolio investment strategies through risk return trade off. In an economy like that of Nigeria, South Africa, Egypt 
and Sudan that heavily depends on oil revenue, practical and urgent steps need to be taken to develop alternative sources of revenue. This is because a fall in world oil prices spells doom for these oil dependent economies.

\section{SUGGESTION FOR FURTHER RESEARCH}

The findings of this study suggests further research on the relationship between oil price and stock market development of each Sub-Saharan country to be conducted separately since the relationship could be different from one country to another which could have important implications for the Sub-Saharan Africa countries' future economic policies and strategies. Also, it could be suggested that more methodologies like ARDL Bound testing; various GARCH families for volatility testing and causality testing between the variables all be further explored.

\section{REFERENCES}

Adaramola, A.O. (2012). Oil Price Shocks and Stock Market Behaviour: The Nigerian experience. Journal of Economics, $3(1), 19-24$.

Akanbi, O.A. (2012). Role of Governance in Explaining Domestic Investment in Nigeria. South African Journal of Economics, 81(4), 473-489.

Akinlo, O.O (2014). Oil Price and Stock Market: Empirical Evidence from Nigeria. European Journal of Sustainable Development, 3(2), 33-40.

Anoruo, E., Mustafa, M. (2007). An Empirical Investigation into the Relation of Oil to Stock Market Prices. North American Journal of Finance and Banking Research, 1(1), 22-36.

Arellano, M., Bond, S. (1991). Some Tests of Specification for Panel Data: Monte Carlo Evidence and an Application to Employment Equations. Review of Economic Studies, 58, 277-297.

Arellano, M., Bover, O. (1995). Another Look at Instrumental Variable Estimation of Error-components Models. Journal of Econometrics, 68, 29-51.

Asaolu, T.O, Ilo, B.M. (2012). The Nigerian Stock Market and Oil Price: A Cointegration Analysis. Kuwait Chapter of Arabian Journal of Business and Management Review, 1(5), 28-36.

Brasher, J. (2004). Oil's Effects on the Stock Market. Call Writter's Money Newsletter: 1-6.

Blundell, R., Bond, S. (1998). Initial Conditions and Moment Restrictions in Dynamic Panel Data Models. Journal of Econometrics, 87, 115-143.

Chinzara, Z. (2011). Macroeconomic Uncertainty and Conditional Stock Market Volatility in South Africa. South African Journal of Economics, Economics Society of South Africa, 79(1), 27-49.

Hamilton, J.D. (1983). Oil and the Macroeconomy since World War II. Journal of Political 14 Economy 92, 228-248.

Hausman, J.A. (1978). Specification Tests in Econometrics. Econometrica, 46, 1251-1272.

Itotenaan, H.O., Amadi, S.N., Moshfique, M.U., Dubon, P. (2013). Oil Price and Stock Market Performance in Nigeria: An Empirical Analysis. American Journal of Social and Management Sciences, 4(1), 20-41.

Imarhiagbe, S. (2010). Impact of Oil Prices on Stock Markets: Empirical Evidence from Selected Major Oil Producing and Consuming Countries. Global Journal of Finance and Banking Issues, 4(4), 15-31.

Jhingan, M.L. (2004). The Economic of Development and Planning. New Delhi: Vrinda Publications Limited. Jones, C.M., Kaul, G. (1996). Oil and the Stock Market. Journal of Finance, 51, 463- 491.

Kaufmann, D., Kraay, A., Zoido-Lobaton, P. (1999). Aggregating Governance Indicators. World Bank Working Paper, 2195.

Kraay, A., Nehru, V. (2006). When is External Debt Sustainable? World Bank Economic Review 20(3), 341-65.

Maghyereh, A. (2004). Oil Price Shock and Emerging Stock Markets: A Generalized VAR Approach. International Journal of Applied Econometrics and Quantitative Studies, 1, 27-40.

Miller, I.J., Ratti, A.R. (2009). Crude Oil and Stock Markets: Stability, Instability, and Bubbles. Energy Economics, 31(4), 559-568.

Muritala, T., Taiwo, A., Olowookere, D. (2012). Crude Oil Price, Stock Price and Some Selected Macroeconomic Indicators: 
Implications on the Growth of Nigeria Economy. Research Journal of Finance and Accounting, 3(2).

Narayan, K.P., Narayan, S. (2010). Modeling the Impact of Oil Prices on Vietnam's Stock Prices. Applied Energy, 87, 356361.

Ogiri, I.H., Amadi, S.N., Uddin, M.M., Dubon, P. (2013). Oil Price and Stock Market Performance in Nigeria: An Empirical Analysis. American Journal of Social and Management Sciences, 4(1), 20-41.

Papapetrou, E. (2001). Oil Price Shocks, Stock Market, Economic Activity and Employment in Greece. Energy Economics, 23(5), 511-532.

Ramos, S.B., Veiga, H. (2010). Asymmetric Effects of Oil Price Fluctuations In International Stock Markets. Working Paper 10-09. Statistics and Econometrics Series (04).

Ross, S.A. (1976). The Arbitrage Theory of Capital Asset Pricing. Journal of Economic Theory, 13, 341-60.

Sadorsky, P. (1999). Oil price shocks and stock market activity. Energy Economics 21, 449-469.

Taheri, N. (2014). The Impact of Oil Price on Stock Markets: Evidence from Developed Markets. Master Thesis Submitted to the Institute of Graduate Studies and Research, Eastern Mediterranean University.

Yadirichukwu, E., Ogochukwu, O.J. (2014). Evaluation of the Weak Form of Efficient Market Hypothesis: Empirical Evidence from Nigeria. International Journal of Development and Sustainability, 3(5), 1199-1244 